\title{
Sagittal and axial mobility of 1st ray in hallux valgus
}

\author{
Kiwon Young ${ }^{*}$, Jin Su Kim, Hun ki Cho, Hyoung Suk Kim \\ From 4th Congress of the International Foot and Ankle Biomechanics (i-FAB) Community \\ Busan, Korea. 8-11 April 2014
}

\section{Introduction}

Hypermobility of the first ray is one causative factor in development and recurrence of Hallux valgus[1],[2],[3]. so treated as an important factor in hallux valgus. While most discussions of 1st ray instability refer to sagittal motion [4],[5], [6],[7]. Increased motion may also be present in the axial plan. However, there is no known way of measuring motion of axial plan. In this study, we assessed the axial plan mobility by means of measuring the difference between weight bearing IMA and nonweight bearing IMA from foot AP radiograph. This study investigated the difference between the axial motion of the first ray of the symptomatic hallux valgus patients group and that of the normal group.

\section{Methods}

A group of 108 women with symptomatic hallux valgus and 37 control women, age 21 to 84 years were measured weight bearing and non-weight bearing IMA and calculated the difference. We measured the 1st ray sagittal range of motion by the EMC device [4]. We moved the first ray up and down and recorded the distance (d). We also measured the first metatarsal length (l) on the AP foot $x$-ray film. Finally, we calculated the 1st ray range of

Table 1

\begin{tabular}{lll}
\hline & Difference between weight bearing IMA and non-weight bearing IMA & Sagittal mobility \\
\hline Hallux valgus group & $3.2^{\circ}\left(\right.$ range $0^{\circ}$ to $\left.14^{\circ}\right)$ & $10.1^{\circ}$ (range $7^{\circ}$ to 16$)$ \\
\hline Control group & $1.2^{\circ}\left(\right.$ range $0^{\circ}$ to $\left.8^{\circ}\right)$ & $7.8^{\circ}$ (range $6^{\circ}$ to 11$)$ \\
\hline
\end{tabular}

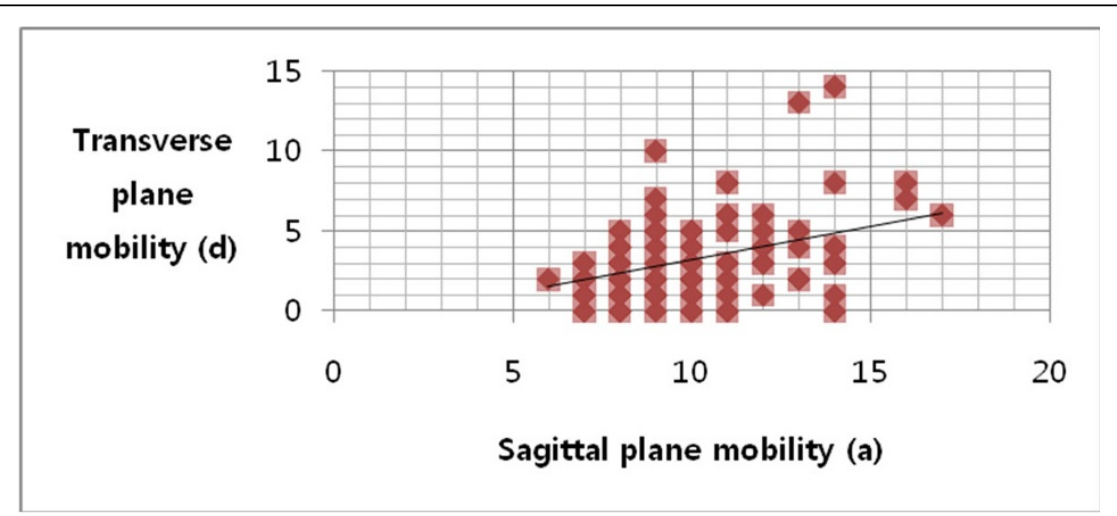

Figure 1

\footnotetext{
* Correspondence: youngkw1@hanmail.net

Dept. of Orthopaedic Foot \& Ankle Eulji Medical College Hospital Nowon,
} Seoul, Korea 
motion (A) using the above data. There data was statistically annalize with correlation with HV angle, IM angle and each other.

\section{Result}

The average of the difference weight bearing and nonweight bearing IMA in the control group was 1.16 and 3.20 in the hallux vallgus group. If we defined 3.6(95 percentile in the normal group) as having axial hypermobility, $42 \%$ of hallux valgus patients had first ray axial plan hypermobility (Table 1 ). The axial plan mobility had no correlation with sagittal plan mobility(Correlation coefficient : 0.25 ) and also no significant correlation with hallux valgus angle or IMA(Correlation coefficient : 0.5) (Figure 1).

\section{Conclusion}

1st ray axial hypermobility is another disease group in hallux valgus, so should be considered in treatment of hallux valgus.

\section{Trial registration}

Clinical experimental study.

Published: 8 April 2014

\section{References}

1. Lapidus PW: Operative correction of metatarsus varus primus in hallux valgus. SurgGynecolObstet 1934, 58:183-191.

2. Lapidus PW: A quarter of a century of experience with the operative correction of the metatarsus varus primus in hallux valgus. Bull Hosp Joint Dis 1956, 17(2):404-421.

3. Coughlin MJ, Grebing BR, Jones CP: Arthrodesis of the first metatarsophalangeal joint for idiopathic hallux valgus: intermediate results. Foot Ankle Int 2005, 26(10):783-792.

4. Lee KT, Young K: Measurement of first-ray mobility in normal vs. hallux valgus patients. Foot Ankle Int 2001, 22(12):960-964.

5. Morton DJ: Hypermobility of the first metatarsal bone: the interlinking factor between matarsalgia and longitudinal arch strains. J Bone Joint Surg 1928.

6. Klaue K, Hansen ST, Masquelet AC: Clinical, quantitative assessment of first tarsometatarsal mobility in the sagittal plane and its relation to hallux valgus deformity. Foot Ankle Int 1994, 15(1):9-13.

7. Voellmicke KV, Deland JT: Manual examination technique to assess dorsal instability of the first ray. Foot Ankle Int 2002, 23(11):1040-1041.

8. Coughlin MJ, Jones CP, Viladot R, Glano P, Grebing BR, Kennedy MJ, Shurnas PS, Alvarez F: Hallux valgus and first ray mobility: a cadaveric study. Foot Ankle Int 2004, 25(8):537-544.

9. Faber FW, Kleinrensink GJ, Verhoog MW, Vijn AH, Snijders CJ, Mulder PG, Verhaar JA: Mobility of the first tarsometatarsal joint in relation to hallux valgus deformity: anatomical and biomechanical aspects. Foot Ankle Int 1999, 20(10):651-656.

10. Rush SM, Christensen JC, Johnson $\mathrm{CH}$ : Biomechanics of the first ray. Part II: metatarsus primus varus as a cause of hypermobility. A threedimensional kinematic analysis in a cadaver model. $J$ Foot Ankle Surg 2000, 39(2):68-77.

11. Bednarz PA, Manoli A 2nd: Modified lapidus procedure for the treatment of hypermobile hallux valgus. Foot Ankle Int 2000, 21(10):816-821.

12. Kim JY, Park JS, Hwang SK, Young KW, Sung $I H$ : Mobility changes of the first ray after hallux valgus surgery: clinical results after proximal metatarsal chevron osteotomy and distal soft tissue procedure. Foot Ankle Int 2008, 29(5):468-472.
doi:10.1186/1757-1146-7-S1-A133

Cite this article as: Young et al:: Sagittal and axial mobility of 1st ray in hallux valgus. Journal of Foot and Ankle Research 2014 7(Suppl 1):A133.

\section{Submit your next manuscript to BioMed Central and take full advantage of:}

- Convenient online submission

- Thorough peer review

- No space constraints or color figure charges

- Immediate publication on acceptance

- Inclusion in PubMed, CAS, Scopus and Google Scholar

- Research which is freely available for redistribution 